\title{
French court upholds use of animals, fines activists for theft of baboons
}

Paris. The French Supreme Court of Appeals last week reaffirmed the right to conduct research on animals and sent an unequivocal message to French animal rights groups that they must operate within the law. In upholding convictions of theft against seven activists who had broken into a CNRS laboratory in 1985 and stolen 17 baboons, the court ends a period of uncertainty over the legal status of such acts in France. Its action is also expected to speed up future prosecutions, including the forthcoming trial of activists accused of stealing more than a hundred animals from an INSERM laboratory in Lyons in 1989 (see Nature 339, 407; 1989).

The baboon raid at the CNRS Laboratory of Neurophysiology in Gif-sur-Yvette near Paris in 1985 was carefully planned as a media event. A professional cameraman was invited to film the balaclava-wearing commandos as they 'liberated' the baboons, many of which carried surgically implanted cranial electrodes. Robert Naquet, then director of the laboratory, first heard of the raid in a telephone enquiry from the news agency AFP; by the following evening the images had been broadcast on the national television news.

The seven individuals carried their costly defence through two appeals with outside financial help and the support of such animal-rights celebrities as Brigitte Bardot and television personality Alain BougrainDubourg. They claimed that the action was justified by the poor care being given to animals sacrificed in the pursuit of useless research, and they sought to have the taking of laboratory animals recognized under a new legal category distinct from theft. They maintained that laboratory animals were not material objects, that wild animals could not be possessed and that the CNRS had not demanded their return. (The CNRS says that the case had received enough publicity and that it did not want to inflame public opinion by trying to reclaim the animals.)

Naquet, a frequent target of the defendants' lawyers, refuted accusations that he had practised vivisection, obtained the animals illegally and treated them badly. He told the court that the experiments were intended to increase understanding of epilepsy, that the species of baboon used (Papio papio) was naturally epileptic and that no other model was available. The fixing of cranial electrodes, he explained, was a painless procedure carried out under anaesthetic.

The court reaffirmed that animal research is a legitimate activity regulated by law: "The CNRS is a public research organization at the centre of scientific and medical discoveries that benefit man", it ruled. The court rejected arguments that the end justifies the means and reminded the seven defendants that other groups had accomplished their aims without violating the law (several of the accused were identified by witnesses as members of the Animal Liberation Front, but all strenuously denied this). The court

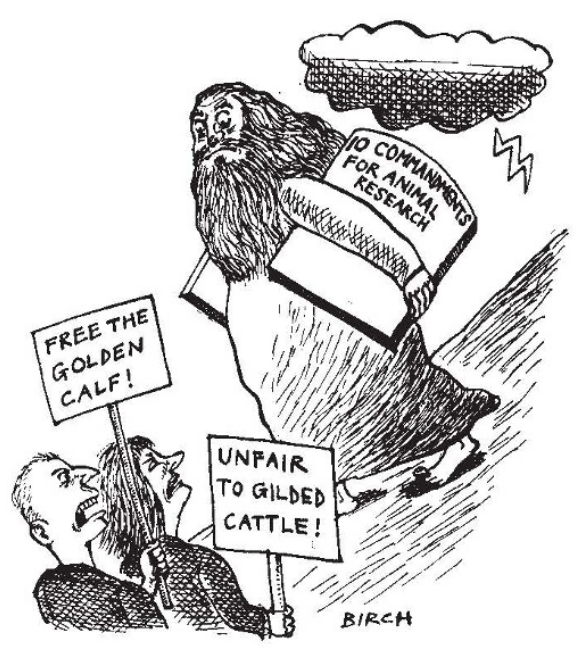

also refused to consider a new category for the taking of laboratory animals, ruling that the baboons were the property of the CNRS and were the target of a common theft.

The seven activists were given suspended prison sentences of up to six months; some were also involved in the Lyons raid, and will go to prison if convicted of that crime. The court also awarded the CNRS damages of FF252,950 (US\$50,000), legal costs of FF7,000 and a symbolic FF1 for the damage to its image. The court also fined the activ- ists FF90,000 for delaying Naquet's research by six months. The CNRS is expected to use the precedent to extract additional payments from insurance companies for delays to research caused by fires or similar events.

The victory vindicates the new hard-line approach taken by French researchers against break-ins by animal-rights activists. In the past, research organizations have kept silent out of fear that any response would elicit further negative coverage by the media. The CNRS's legal offensive has been paralleled by a campaign by the Ministry of Research and Space to win over the public to the need for animal research.

In January this year, Hubert Curien, Minister for Research and Space, launched his " 10 commandments for animal research" at a press conference. Animal experiments in France are already regulated under a 1987 act based on European legislation, but Curien felt that public concerns needed to be addressed further. To this end, he introduced a uniform animal research policy throughout the various organizations that would include the regular publication of statistics, training for researchers, renovation of facilities, closer contact with the veterinary profession, alternatives to animal experimentation and the requirement that all laboratory animals be obtained from specialized breeding institutes by the end of 1993 .

Curien's crusade has weakened the animal activists' monopoly on the media. His "10 commandments" were widely and favourably reported in the French press, as were statistics released last month showing a drop of 24 per cent in the number of animals used in public and private laboratories between 1984 and 1990 .

Declan Butler

\section{Blow struck against US pork-barrel}

Washington. The victory may be fleeting, but US Representative George Brown (Democrat, California) last week struck a surprising blow against the time-honoured practice of feathering the research nests of members' home districts.

At issue was the spending of $\$ 94$ million on ten academic facilities that had neither been requested by the relevant federal agency nor received peer review but had, instead, appeared at the eleventh hour in an appropriations bill for the forthcoming 1993 fiscal year that includes the Department of Energy. (The bill, among other items, includes $\$ 517$ million for the Superconducting Super Collider, some \$133 million less than the Bush administration had requested.)

Brown, chairman of the House science committee, took advantage of a little-used parliamentary manoeuvre to win a $250: 104$ vote that stripped out the so-called porkbarrel projects and, in their place, permitted $\$ 100$ million to be spent on facilities that have been authorized by Congress and reviewed competitively. Supporters of the projects are expected to find an equally obscure way to try to reclaim the money in the Senate version of the bill, but Brown has made it clear that he may oppose any money bill that contains similarly unauthorized research facilities.

Jeffrey Mervis 